DOI: $10.15503 /$ jecs20141-320-333

\title{
VIETNAMESE PARENTS AND CZECH NANNIES: SECOND-GENERATION IMMIGRANT CHILDREN AND THEIR EDUCATORS ${ }^{3}$
}

\author{
ADÉlA SOURALOVÁ \\ Department of Sociology, \\ Masaryk University in Brno, Czech Republic.

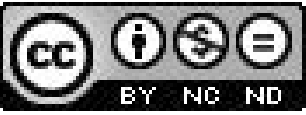 \\ E-mail adress: asouralo@fss.muni.cz
}

\begin{abstract}
Many second-generation Vietnamese immigrant children in the Czech Republic are brought up by Czech nannies. While their parents are incorporated into the labour market in order to provide their children with sufficient economic capital for their education, the role of caregivers is relinquished to nannies. Both parents and nannies become important actors in the children's educational process, from the stage of acquiring first words, through primary school, to the moment they are admitted into university. This paper analyses the roles of parents and nannies in this educational process. It draws upon 60 interviews conducted with first-generation immigrant mothers, second-generation immigrants, and Czech nannies. The perspective of all three actors are presented here in order to reveal the interviewee's understanding of the role of education in the parent-child and nanny-child relationships. How is education manifested in the definitions of parenting and caregiving? The paper illuminates the educational strategies taking place outside the educational institution as being an inherent part of everyday life. Simultaneously, the article reveals the meanings of education for the immigrant families as being linked both to past experience and future expectations.
\end{abstract}

Key words: second generation immigrants, education, caregiving, parenting

"For their future, education is the most important." (Ms. Duong, ${ }^{4}$ mother of two children)

"I know she loves me because she cares about me and she provides me with money for my education."

(Lien, 18-year-old)

"They like learning, these kids. The girl comes and tell me »auntie, come, we will play school«. And I say »come on, dear! « And she sits and copies phrases from newspaper. Now she is in the first grade and she knows the alphabet, she knows multiplication, she knows everything."

(Ms. Jestřábová, nanny of Vietnamese children)

This article was written with the support of the Czech Science Foundation, under the research project "Educational strategies of migrants and ethnic minority youth" (P404/12/1487).

4 All names have been changed. 


\section{INTRODUCTION}

Over the last couple of decades, there has been growing research interest in the educational strategies of minority and/or immigrant families across Europe (Ní Laoire, Carpena-Mendéz, Tyrrell, White, 2011; Fangen, 2010; Szalai, 20105). As Ní Laoire et al suggested: "the heavy emphasis on educational attainment reflects public anxieties around the future integration of populations that are perceived to be different and to not belong" (Ní Laoire et al, 2011, p. 6). Increasing immigration to the European Union countries goes hand in hand with growing ethnic diversification and ethnic stratification "with the native majority population placed at the top and minorities at the bottom of the hierarchy" (Heath et al, 2008, as cited in: Strömpl, Kaldur, \& Markina, 2012, p. 87). As Lucie Jarkovská, Kateřina Lišková and Jana Obrovská (Unpublished article) argue, in the Czech Republic the children of immigrants are a relatively new element in school classrooms, which in the 1980s and 1990s used to be filled with ethnic Czechs. Among these children, the offspring of Vietnamese immigrants constitutes a group of significant size: in the school year 2011/2012, of all foreigners, there were $27.5 \%$ Vietnamese children attending kindergarten, $19.9 \%$ going to primary school, and $26.4 \%$ being signed up for secondary school (Czech Statistical Office, 2013).

With a total number of 60000 , Vietnamese are the third-largest group of immigrants in the Czech Republic, after Ukrainians and Slovaks. By contrast with other immigrant groups, it is typical of the Vietnamese minority to have a progressive demographic structure, meaning that the percentage of children under the age of 14 is high (in 2005 it was $21 \%$, compared to $15 \%$ in the majority groups). Also, compared to other immigrant groups, the image of the Vietnamese second generation as high achievers in the Czech education system is being perpetuated. Second-generation Vietnamese are viewed as successful, fluent in the Czech language, linguistically integrated into the majority since early childhood, and achieving the best positions at universities in early adulthood. ${ }^{6}$ Finally, in comparison to other immigrant groups, for Vietnamese a diversity of actors participating in the educational process of children is not a novelty. It is quite common of Vietnamese parents to hire Czech caregivers and private teachers to provide their children with care and to help them with learning not only the Czech language but later with other school subjects as well, all this while the parents are focused on earning a living. It is usually the nanny who assists the child with doing homework assignments and who is asked to help when the child does not completely understand the curriculum.

This article analyses the roles of Vietnamese parents and Czech nannies in children's educational process. It draws upon 60 interviews conducted with first-generation immigrant mothers (25 interviews), second-generation immigrants (20 interviews), and Czech nannies (15 interviews). The perspective of all three actors are presented here in order to reveal the interviewee's understanding of the role

See the results of the comparative research EDUMIGROM on http:/ / www.edumigrom.eu/.

Research on second-generation Vietnamese shows differences within the population depending on the time of parents' arrival and level of assimilation (Jánská, Průšvicová, \& Čermák 2011; Hrdličková, 2010). 
of education in the parent-child and nanny-child relationships. How is education manifested in their definitions of parenting and caregiving? How do the actors reflect upon their relationship with each other, and what role does education play in these relations? The article attempts to reveal some of the educational strategies taking place outside the educational institutions as a regular part of everyday life. In addition, it demonstrates how education becomes one of the main activities and aspects of parent-child and nanny-child ties.

\section{RESEARCH DESIGN}

The data presented here were collected between 2010 and 2013 as part of two related research projects. The first was done between 2010 and 2012; its main topic was the character of relationships and ties between children, nannies, and mothers (Souralová, 2013). 15 interviews with mothers, 15 interviews with nannies, and 20 interviews with second-generation children were conducted, recorded, transcribed and analyzed. These interviews were primarily focused on the issues of caregiving, parenting, and upbringing in a country that is not the homeland of one's parents (the issues of ethnic identity) and by a person who is not a parent (the issue of kinship and family ties). An essential part of the interviews was the topic of education. The interviewed mothers talked about their children's educational success, about the importance of education in their lives, and about the role of Czech nannies in the children's educational process. The nannies usually praised the children they looked after for their diligence and hard work. But they also commented on what was in their eyes the parent's inappropriate pressure on children with regard to education, or lack of time spent by parents with their children. The interviewed children talked both about their parents providing them (financial) support for their studies and about their nannies who taught them the Czech language and who helped them with their homework when they needed it. All these stories indicated that education plays an important role in the lives of all these actors, as it is accentuated throughout the interviews.

In the second phase, as part of the ongoing research under the title Educational strategies of migrants and ethnic minority youth, I conducted 10 interviews with Vietnamese parents who have at least one child in primary school. These interviews focused on education alone, and examined how parents form educational strategies for their children within the post-migratory context, and how, in retrospect, they make sense of their experience as immigrants. The interviews revealed the centrality of children's education in parents' comprehension of their migration project, as well as their parenting.

The analysis presented in this paper focuses on education and its role in an emic understanding of children's ties with their parents and nannies (and vice versa). Importantly, it is not the only facet of their relationship, nor is it the most important one. Instead, my analysis is driven by the following questions: What is the significance of education in the child-parent relationship? How is the problem of education negotiated in the context of nanny-child ties?" My analytical strategy, then, was to start with education and see through this prism the inter- 
personal relationships between the involved actors. The article seeks to reveal the mothers', children's and nannies' comprehension of the meanings of education in immigrant families as something linked both to past experiences and future expectations.

\section{PLACE OF EDUCATION IN CHILD-PARENT RELATIONSHIP}

This section deals with the parent-child relationship and the role of education in determining what it means to be a parent for the Vietnamese first-generation immigrants I interviewed, and what it means to be a child of Vietnamese immigrants for the second generation I interviewed. While tracing how parents and children talk about education, I focus on how they define their relationship with each other. In other words, one of the premises of this study is to elucidate the emic understanding of parenthood and childhood through the issue of education and the ways education is spoken of in relation to child-parent ties. In what follows, I isolate five roles of parents that recur in the interviews. All these roles must inevitably be connected with the parents' migratory experience and the post-migratory context. As such, they provide an essential background in which the stories are narrated and relationships are knitted, negotiated, and interpreted by the interviewees.

Parents as creators of opportunities: The interviews, on the whole, reveal that there is a direct link between the migration project of the first-generation parents and the education of second-generation children. If we look at the Vietnamese immigration to the Czech Republic, we find out that its roots date back to the time long before 1989. Under agreements between two socialist states, the Czechoslovak Socialist Republic and the Socialist Republic of Vietnam, thousands of Vietnamese people had been settling down in Czechoslovakia since the 1970s. They worked in factories or studied at vocational schools. After the fall of communism in 1989, the state-managed migration turned into labour migration. The common pattern among the parents I interviewed was that they came in the 1980s under some bilateral agreements, returned to Vietnam after 1989, and in the 1990s came again to the Czech Republic. In this context, either with or without any prior experience of studying or working in the Czechoslovak Socialist Republic, Vietnamese immigrants have come to the Czech Republic to realize their migratory project. One topic that repeatedly arose in all the interviews was the interviewees' interpretation of the meaning of their journey to Europe. The parents usually said that "we came to the Czech Republic to live a better life," meaning to find better working conditions, better paid jobs, and provide children with a better educational system. The interviewed children often emphasized the fact that their "parents came to provide us with better living conditions, and now they stay just because of us." Their parents play the role of creators of opportunities because their migratory project is entirely children-oriented: the parents came to the Czech Republic for their children, working intensively to provide them with economic capital for their studies, but they also want return to Vietnam when their children are adult and independent.

This kind of reasoning is communicated to the children in order for the children to know why their parents came to the Czech Republic, and in order to make 
clear that their coming here generates a set of opportunities that must be taken advantage of by the children to guarantee the success of their parents' project. Lien, a 17-year-old girl born in the Czech Republic to first-generation Vietnamese immigrants, described how her parents imagine their future:

"They live here in Czechia to work hard, to have money for their children's education. And when their children are educated, everything they aimed at will be fulfilled. So they did their job and the children do not need them anymore, and this means that they can return to their homeland where they have their friends and relatives. Later there will be nothing keeping them here."

What this quotation makes evident is the children's understanding of their parents' post-migratory lives as being oriented toward their well-being. The children in my sample perceive their parents' immigration as both a way of creating opportunities and of imposing burdens, both of which seem to go hand in hand. The awareness of their parents' sacrifice to ensure a better life for their children motivates the latter to study hard. As one of my informants said, "we want to learn, it is not just that we should." The pressure to accomplish what the parents have planned for them is for many of my interviewees the main force pushing them to become high achievers in the education process.

Parents as sponsors of success: The opportunities that resulted from the parents' migration can be fully used only if the children are equipped with sufficient economic capital. This economic capital can be then transformed into cultural capital (Bourdieu, 1986). When analyzing the parents' role in their children's education, we must therefore in the first place address the parents' breadwinning activity, which significantly shapes their post-migratory everyday lives. For the Vietnamese community scattered across the Czech Republic and the countries of Central Eastern

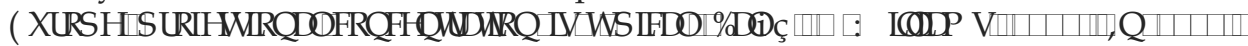
around 88000 (63 000 men and 25000 women) of foreigners in the Czech Republic held a valid trade license, with some 36000 of them being Vietnamese (25 000 men and 11000 women, $41 \%$ of all foreigners-holders). The reason for such occupational concentration can be found in the early 1990s, when establishing a business license was a way to formalize and legalize residence for immigrants who came under the former agreements between the Czechoslovak Socialist Republic and the Socialist Republic of Vietnam (Brouček, 2003). Self-employment is therefore the main characteristic of the post-migratory work life of first-generation Vietnamese immigrants, and it has an impact on every aspect of their lives.

Becoming part of the migrant economy entails two essential changes in Vietnamese parents' work biographies. The first change is qualitative and causes re-specialization of their work lives. Regardless of their profession before their arrival in the Czech Republic and regardless of their education, specialization, or skills, the majority of my informants, after coming to the Czech Republic, automatically become part of the immigrant economy. They mostly start working as entrepreneurs or owners of shops. It is usually connected with downward professional mobility (see below). The second change, quantitative, profoundly re-directs their time investment into breadwinning activity. As many interviewees acknowledged: 
"They work there [in Vietnam] normally as Czech people do here, up to five-six pm. And after work they have their free time, they have their families. We work there, but we have leisure time and the time for our families. But it is not here. Here it is simply every day at work."

(Patrik, second-generation immigrant)

"It is impossible for them to close their shops for a week or two and go for a holiday with the family. They are able to pay so much money for their children's education; for example, they are able to send them to England for two or three weeks to learn the language. And it is very expensive. And this they are able to pay, but to take the children and go for holiday, it is a waste of time, they would say."

(Ms. Nguyen, first-generation immigrant)

In general, what these excerpts show is how hard it is for the parents to maintain the balance between work and family life. "Doing everything for the children while not being with them" - this is how their reconciliation of work and family life can be summarized. The Vietnamese parents' parenting, therefore, seems to be primarily enacted in the labour market, while the task of caregiving is usually assigned to Czech nannies (see next section).

Parents as founders of aspirations: For many interviewees, the educational aspirations of children are based on the awareness that their parents did not have the same opportunities and that their chances of studying were limited either because of the lack of economic capital necessary for university studies or because of the rupture in their professional careers caused by migration. One of my mother-interviewees described her own achievements in the field of education back in Vietnam. She had a degree in law, but her husband decided to leave for the Czech Republic and she decided to accompany him. Together they started their business in a new country. The downward occupational mobility caused by that decision affected not only her work life but also her children's educational strategies. Ms. Van and Ms. Trinh, both mothers of two children, explained the motivations of their children to study hard:

"I think my children are so successful because they know that we, me and my husband, we did not have these opportunities. We could not study and now we are working here [in wholesale]."

"My daughter wants to be a lawyer. I think it is because she knows I also studied Law faculty in Vietnam. So she wants to continue (laughs)."

From such a point of view, the role of parents' education opportunities, and lack thereof, is seen as a basic stepping stone to the children's education. The children, as their parents assume, will aim at accomplishing their (parents') ambitions. Hence, they study not only for themselves, but also for their parents, which may put them in a situation marked by considerable pressure and expectations. The issue of pressure appears quite often in the interviews, as I will show in the section that follows.

Parents as supervisors of education: Despite their extensive working hours, the parents very often find occasion to speak with their children about their school 
achievements. In the daily practice of parenting, they ask about the children's day every time they come home from work. The nannies, for their part, usually comment on such parents' behavior with huge criticism and view the parents' emphasis on education as inappropriate. For example, Ms. Jestrábová, the nanny of three children, confessed,

"I observe it every day. I come to their home and all they ask is if they have homework, right? All they do is push the school. They never ask, what did you do and how were you today, did you just study? Study, study, study."

The nannies also compared their own children with the children in their care in terms of how much time they spend studying and preparing for school, and what their grades are. While the nannies saw this as a combination of the parents' pressure and the somewhat "natural" diligence of children, the mothers rejected the idea that they were putting their children under too much stress. They preferred the explanation that children "just do it because they want it themselves." The Vietnamese parents described the positive motivations of their children: they reward their children with some money or small gifts for every good grade they get.

The critical moment in child-parent ties comes after the child starts receiving bad grades (either ordinary grades or grades on certificate). Here again this is usually acknowledged by the children and/or by their nannies, rather than by mothers. In this context, Ms. Havranová, the nanny of nine-year-old boy, recalled:

"He is afraid of his father because he immediately grumbles about him. They are at work all the time but they want their children to be excellent. And Chien is fed up with it. Once he passed a test in mathematics and got 1 point less than was necessary for an A+. And the father started screaming at him »I pay for your expensive lessons in Math and you..." "

The relatively tough criticism directed by the nannies towards parents' parenting and pressure (as in the excerpt above) was offset by the children's own accounts. However, an extreme rather than a typical case in my sample was Linh, a 19-year-old girl, who had lived and been raised by her Czech nanny until she turned 13. The sudden return to her parents brought a big change in her life, including her approach to education. Linh was the most competent in identifying the differences between the "Czech way" and the "Vietnamese way" of supporting children.

"Vietnamese parents do not directly motivate their children by saying nice things to them. On the contrary, my parents disparaged me all the time, they criticized me and pointed out to other children and to how great they are. And I was the bad one. They supposed it would motivate me to get better and better grades. However, for me it had a completely different effect because I felt so sorry and very hurt."

Such fierce criticism levelled at her parents pervaded the whole interview with Linh. But unlike Linh, other children-interviewees were more careful in judging their parents' parenting and their emphasis on education. They admitted that their parents (or, generally, all Vietnamese parents in the Czech Republic) were 
quite strict and pushy in directing their children to study hard. Nevertheless, at the same time they softened these statements by emphasizing their parents' intentions to provide them with a better future through ensuring access to first-class education.

Parents as providers of a better future: Summarizing what has been said so far, the last question that has to be addressed here is why parents do sacrifice their time for work and not for time spent with children. One simple answer is that they want to provide their children with a better future, that is, to ensure a better quality of life than they had. In her research on Asian mothers in Australia, Pranee Liamputtong (2006) demonstrated that the women in question define the success of their mothering in relation to their children's success in education and on the labour market. The emphasis on education is therefore an essential part of the definition of good parenthood/motherhood. This is apparent in the following quotation from the interview with Ms. Duong, the mother of two children:

"For their future their studies are the most important now. If they study hard they will graduate, and it will be easier for them to find a job anywhere. That is why they must study now."

In this context, education is seen as the means to climb the social ladder and escape the confines of the so-called immigrant economy. The interviewed parents do not want their children to follow in their parents' footsteps. Moreover, they find idea that their children would take over their shops as unacceptable in light of all their efforts and money they have invested in their children's education. These education achievements are not accumulated per se, but are perceived as the only way for second-generation children to integrate into the Czech society. In addition, for the Vietnamese parents it is not only important that the child should be educated, but that he/she should have the best education, and that their grades should be better than those of their Czech colleagues. Only then can they overcome the stigma of being foreigners and, eventually, be viewed positively by future employers, who will not automatically turn down their applications in favour of the Czech candidate.

Thus, providing a variety of educational opportunities appears to be the main goal behind the parents' migratory project. Educational success leading to successful integration into the labour market is presented in the narratives as a mark of good parenthood. The interviewees' interpretations of the role of parents in their children's education process consequently rest on the above assumptions, with education being considered an important aspect of parent-child ties. It is not only because both children and parents see the migration of the first generation in terms of achieving a better life (which is attained through education), but also because education usually becomes one of few shared topics of conversation between the children and their parents. In other words, education is manifested in the parent-child relationship on many different levels. However, all of them refer to the post-migratory experience of parenting and to the imperative to grasp the opportunities inherited from the elderly. 


\section{NANNIES AS EDUCATORS AND EDUCATION GUARDIANS ${ }^{7}$}

Many children of Vietnamese immigrant parents living in the Czech Republic are brought up by Czech nannies. Their first-generation immigrant parents seek to hire Czech nannies to take care of their children while they are working (mostly as self-employed entrepreneurs selling clothes or owning restaurants), and to equip children with the kind of knowledge that they themselves cannot provide (language skills, transmission of cultural memory, etc.). There are several reasons why Vietnamese parents hire Czech nannies, suffice it to mention extensive work hours, absence of kinship support, and insufficient state support for nursery schools. The nannies are hired to look after children of different ages: some of the children included in my sample started being cared for when they were only a couple of months old (if they were born in the Czech Republic), others from the time they were young children (typically immediately after their arrival in the Czech Republic).

This section looks into the way the interviewed children and their parents perceive the role of the nanny in the children's lives, including their educational process. Caregiving entails not only nurturing but, above all, the transmission of skills, as well as social and cultural capital (Macdonald, 2010; Bourdieu, 2001). The role of nanny, then, is a formative one in the whole process of upbringing and education. It must be said that hiring a nanny is rarely defined beforehand in terms of education: the nanny is hired not to educate the child and help him/her with integration into the Czech society, but to serve as a substitute for the working mother. With regard to education, nannies play three basic roles. They are inevitably presented as caregivers, very often primary caregivers, of crucial importance for children's up-bringing. Second, during the daily practice of caregiving they transmit an informal curriculum to the children they care for. Third, the nannies play an important role in the children's schooling, helping them with their school work and when communicating with school institutions.

Nannies as caregivers: Czech women are hired by Vietnamese families to perform caregiving work. This work entails ensuring the child's well-being (such as feeding and security), but also other activities which are directed at the fulfilment of things other than basic biological needs. It is the nanny who is responsible for the child's intellectual development from his/her early childhood. This point seems especially important with respect to language socialization. Providing that the child spends more active time with nannies, in many cases the nanny plays a key role in the child's language socialization.

During my research I observed a huge discrepancy between the parents' (first-generation migrants) and (second-generation) children's knowledge of the Czech language. It appears to be a relatively common pattern for immigrant groups, as well as the logical outcome of the fact that migration may have a different impact on different people at different life stages. It has been repeatedly shown that children are faster in acquiring a new language than their parents (Kibria 1993; Zhou,

An earlier version of this section was presented at the 2nd Belgrade International Conference on Education. 
\& Bankston, 1998 etc.). For Vietnamese immigrants in the Czech Republic, this gap is caused, above all, by the racial segregation of the first generation on the Czech job market (minimized contact with Czech native speakers, which is due to extensive working hours and due to the limited vocabulary necessary for performing this job) and the relatively high level of the second generation's integration into the majority. Second-generation children attend Czech schools, are surrounded by Czech peers and friends, and many of them (in my sample almost all) consider Czech as their first language (Vietnamese has the status of maternal language for them). Developing skills in the Czech language in many cases leads to a decline in the use of the "home" or "maternal" language. Noteworthy, the interviewed children complain about not being able to speak with their parents fluently.

As the collected children's accounts show, the nanny, just like Czech peers, is seen as a key actor in facilitating language socialization. One of the interviewees, $\mathrm{Thu}$, born in the Czech Republic and now 18 years old, said:

"For my future I must know the language of the country where I live. Only then can I study. And this my parents could not provide me with."

Starting from early childhood, the nannies teach them children's poems or songs. In the interviews, they boast how many words the little children can say, while their parents fall behind them. In cases when the child is cared for by the Czech nanny from the very early age of development, the first word will usually be said in Czech (and not Vietnamese). The nannies express their need to be appreciated for giving the children such a foundation for their future education. Even though language socialization is not the main reason why parents hire Czech nannies, it is very often retrospectively seen as the biggest advantage of delegating the caregiving task and making it easier for the children to integrate into the educational system.

Nannies as transmitters of the informal curriculum: In the daily practice of caregiving, it is not only the language that is transmitted, but, more importantly, ideas, meanings, values, and traditions that are passed from nannies to children. These values are inevitably class-based and ethnicized, as they are shaped within a particular historical, socio-cultural and economic context. When families hire caregivers, they usually have to deal with the question of how to transmit particular norms and habits. This is true especially in cases when the job is performed by immigrant (and poor) women for upper-middle class families (see: Macdonald, 2010). Nevertheless, in the case of Czech nannies in Vietnamese immigrant families, the socio-cultural bias in upbringing is welcomed and valued, because the Vietnamese parents believe it may help their children better understand the society in which they are raised.

What is the informal curriculum and how it is transmitted from nannies to children? In the interviews, the children repeatedly referred to Czech customs with which their parents are not familiar, but which, nevertheless, are an important part of "life à la Czech." Christmas and Easter were the most prominent holidays. Colouring Easter eggs, baking Christmas cookies, or decorating the Christmas tree-all these activities were mentioned in the interviews as essentially connected with the 
figure of the nanny. Likewise were pig- slaughtering, fishing, summer work in the garden, picking mushrooms. All these activities were cited by the children to explain what they were able to experience thanks to their nannies and which would otherwise be impossible with their parents (either because of the lack of time, or because it's something the Vietnamese don't do). Apart from these, the nannies' transmission of the informal curriculum occurred on still other occasions. All of them experienced it at the spontaneous level, rather than as part of a premeditated educative strategy. Taking trips around the Czech Republic (visiting sites of crucial significance for Czech culture, such as castles, important towns etc.), telling children about the different holidays - all of these were not felt as history or geography lessons, but as a part of daily family life as experienced with nannies.

One last question remains, namely, how the role of nannies is perceived by the children, and how they acknowledge its importance in their lives. The interviewed children speak of the role of the nanny as related to the role of the institution of school. As they confessed, they were able to live like the Czechs do, not just observe them as outsiders. Whereas the classroom can teach children about events, habits, traditions, the nannies make it possible for the children to experience those traditions and habits personally and to understand it as part of their own lives. The exanimated accounts point to the formative role of caregiving also for children's understanding of their social position in the Czech Republic.

Nannies as at-home educators and helpers: In view of the parents' focus on work and their relatively poor language skills, the role of the nannies in helping the Vietnamese children with school preparation comes to the fore. It is especially at the first educational stages that the nanny is irreplaceable. Later, when the curriculum becomes more difficult and classmates become more important for the children, she is replaced by the peer group. This was also the case of Minh, a seventeen-year-old boy, was born to a first-generation immigrant mother who came to the Czech Republic in the 1990s. When Minh was less than one year old, his mother had to return to the workplace, so Minh started living at his nanny's (his mother came every evening after work to see him). When he was small, he liked watching Czech fairy tales on television. Later, when he started primary school, his nanny helped him with his homework. He recalled:

"She taught me everything. When I came home after school, she did my homework with me and tutored me. It was much better than with my mum because with her I would not have done it, she couldn't have checked it for me. (...) And I was very curious, I asked her about everything, I think it bothered her quite often [laughs]. But she always explained everything to me. All I know, I know from her."

Now Minh is almost an adult, but he is still in touch with his nanny. She cannot help him with his homework now, and when he needs something, he asks his friend or looks it up on the Internet. But when he was small, the nanny was his main helper and advisor. This model appears in all interviews, and I would dare to say that for all the interviewed children their nannies are the primary helpers at the beginning of their education. 
The extent of the nanny's involvement in a child's education varies across my sample depending on the age of the child (the older the child is the more he/she seeks help elsewhere) and the educational background of the nanny (less-educated nannies usually find neighbours or friends to help them with more difficult tasks). With older children, private tutors hired by the parents can appear more important than the nannies, who may remain in the child's life as grandmothers. However, at the beginning of the educational process the nannies in my study would help children with basic tasks, thus substituting for parents, who usually cannot be helpful because of the language barrier, as discussed above and as evident in Minh's experience.

Nannies as communicators with educational institutions: In interacting with the institution of school, the nanny becomes the contact person and mediator between school and parents. In some cases she is the one who signs the child's record book and who communicates with teachers at school and attends parent-teacher meetings. Communication with the school may start quite early, as many nannies are asked to find a kindergarten and sign the child up for it. This continues at primary school, when regular parent-teacher meetings take place. Such an arrangement is not institutionalized, and is based on face-to-face interactions between teachers and nannies (who are backed by the parents' wishes). Even if the nanny persuades parents to go to parent-teacher meetings, they usually decline, saying that they "would be useless there". Both for teachers and parents it is a win-win situation, as the language barrier would otherwise make discussion of the children's school education quite difficult, if not unfeasible. However, such delegation may have a direct impact on parents' opportunities to get out of the immigrant economy and community and start establishing contacts with the majority group. If these activities are delegated to a third party, the parents are not "pushed" to stay in touch with members of the majority, and in many cases they miss the opportunity to establish bonds between themselves and other (Czech) parents.

For the nannies, communicating with educational institutions means taking on additional responsibility. Such responsibility may be either welcomed (as the nanny becomes an expert in the child's life) or unwelcomed (when the nanny insists that the parents must take on some of the responsibilities of childcare). The former attitude is prevalent, and the nannies approach these tasks with enthusiasm and a great deal of organization. So does Ms. Zezulková, a former primary school teacher:

"I have one special shelf at home where I have all these things, all documents of children from school. Their mother suddenly realized she did not know where the kids have their pupil's record books and that she never saw them. And I told her »if you want to see it, come to me, I have it all at home«. [Adéla: So you have all of this?] I made photocopies of everything, even of some exercise books because they write so nicely. So I have it all. Also I have everything on a calendar - when children should go to the doctor. This I organize, too."

All in all, the nannies in many cases become not only intermediaries between school and parents, but in fact the ones responsible for carrying out an educational plan for the children that was earlier designed by the parents. 
To sum up, though hired as caregivers, the Czech nannies become educators and teachers for the children of Vietnamese parents living in the Czech Republic. This extension of their role occurs spontaneously as daily contact between nanny and child brings new tasks (teaching the first words, activities connected with particular times of the year, or enjoying leisure time and or outings) as the child grows up, enters school, and the nanny takes on the parents' role of helping and advising in the educational process itself.

\section{CONCLUDING REMARKS: CONTINUITY AND PRESTIGE THROUGH EDUCATION}

This article has focused on the role of education in the lives of Vietnamese immigrants in the Czech Republic. It has examined the ways in which parent-child and nanny-child ties are perceived by first-generation immigrant parents, second-generation immigrant children, and their Czech nannies, and how these three groups link their roles and responsibilities toward one another with the children's education. Both for parents and for nannies, a highly-educated child is seen as the successful accomplishment of their endeavours (parent and nanny), and as a mark of successful parenting and caregiving.

For the interviewed children, their educational achievements are rarely described as an individual matter. Instead, when analyzing the role of education in parent-child ties knitted as part of the post-migratory re-settlement, it becomes evident that education is a family matter in at least two respects. First, the children's education should ensure the continuity of life in the Czech Republic. As the children go through different educational stages, the migratory mission of parents is being meaningfully realized, and the sacrifices that the parents have made for their children are passed along for the well-being of next generations. As I argue in this paper, such meaningful continuity is only achieved by professional discontinuity between the parents' generation and the children's generation (meaning that the children are not expected to take over the parents' business in the Czech Republic).

Second, the children's educational achievements bring prestige to the whole family, and, above all, to those parents who follow the argument that an educated child is an integrated child. That is why education is said to be the most important aim of parenting. The success of a child means the success of the family, of parenting, and a sign of good parenthood.

"Generally Vietnamese parents are very strict. For example, when you study you cannot have a boyfriend, because the only thing you can focus on is your studies. You do not have to work, you do not have to do anything, just study. And when you get good grades, the parents love to present it everywhere. They like bragging, especially bragging about what their children have done well, what they have achieved. It is something like a trophy."

The above analysis of the interviews has made it clear that such an insight into the emic meanings of education in interpersonal ties reveals broader meanings 
of education for immigrant families, which are linked both to past experience (of migration) and future expectations (of integration).

\section{REFERENCES}

Bourdieu, P. (2001). "The forms of capital," in Granovetter, M., Swedberg, R. (eds.). The sociology of economic life. Boulder and Oxford: Westview Press, p. 96-111

Brouček S. (2003), Aktuální problémy adaptace vietnamského etnika v ČR [Current problems of the Vietnamese adaptation in the Czech Republic]. Praha: Etnologický ústav AV ČR.

Czech Statistical Office (2013) Children, pupils and students at nursery schools, basic, secondary and higher professional schools and conservatories: by citizenship; school year 2011/12. Retrieved from http:/ / www. czso.cz/csu/cizinci.nsf/t/11004A0B99/\$File/c06t01.pdf.

Fangen, K. (2010). Social Exclusion and Inclusion of Young Immigrants. Presentation of an Analytical Framework. Young - Nordic Journal of Youth Research, 18(2), 133-156.

Strömpl, J., Kaldur, K., Markina, A. (2012). Pathways in Education. In: K. Fangen, T. Johansson, N. Hammaren (Eds.). Young Migrants. Exclusion and Belonging in Europe (pp. 87 - 116). London, New York: Palgrave Macmillan.

Hrdličková, Z. (2010). Dílčí postřehy o postojích českých učitelů Nçi Nỉm z Vietnamu, Číny a Mongolska [Reflections on the Attitudes of Czech Teachers toward the Pupils from Vietnam]. In: I. Barešová (Ed.), Současná problematiká východoasijských menšin v České republice [Current issues of East-Asian minorities in the Czech Republic] (pp. 98-110). Olomouc: Univerzita Palackého v Olomouci.

Janská, E., Průšvicová, A., ČHP i N『 príklad základní školy Praha-Kunratice. [Possibilities for Researching the Integration of Vietnamese Children in Czechia: The Example of Prague-Kunratice Elementary School.] Geografie, Vol. 116, No. 4, 480-496.

Jarkovská, L., Lišková, K., Obrovská, J. (Submitted for Publication). “We treat them all the same but..." Teachers dealing with the disappearing ethnic homogeneity in Czech classrooms.

Kibria, N. (1993). Family tightrope: the changing lives of Vietnamese Americans. Princeton: Princeton University Press.

Liamputtong, P. (2006) Motherhood and "moral career": Discourses of good motherhood among Southeast Asian immigrant women in Australia. Qualitative Sociology, 29(1), 25-53.

Macdonald, C.L. (2010). Shadow mothers. nannies, au pairs, and the micropolitics of mothering. Berkerley, Los Angeles, London: University of California Press.

Ní Laoire, C., Carpena-Mendéz, F., Tyrrell, N., \& White, N. (2011). Childhood and Migration in Europe. Portraits of mobility, identity and belonging in contemporary Ireland. Farnham: Ashgate.

Souralová, A. (2013). Vietnamese Immigrant Families and Czech Nannies: Mutual Dependency, Emotionality, and Kinship Ties in Caregiving (Doctoral Thesis). Brno: Masaryk University.

Szalai, J. (2010). Being "Visibly Different": Experiences of Second-generation Migrant and Roma Youths at School. EDUMIGROM Comparative Papers, Budapest: Central European University, Center for Policy Studies Retrieved from: http://www.edumigrom.eu/sites/default/files/field_attachment/page/node-5387/edumigromcomparative-community-study.pdf.

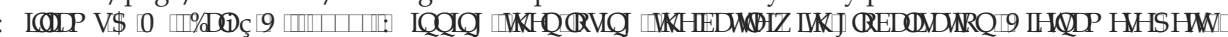
traders in Slovakia, International Journal of Urban and Regional Research, Vol. 29, Issue 3, 533-549.

Zhou, M, \& Bankston C.L. (1998). Growing Up American: How Vietnamese Children Adapt to Life in the United States. New York: Russell Sage Foundation. 